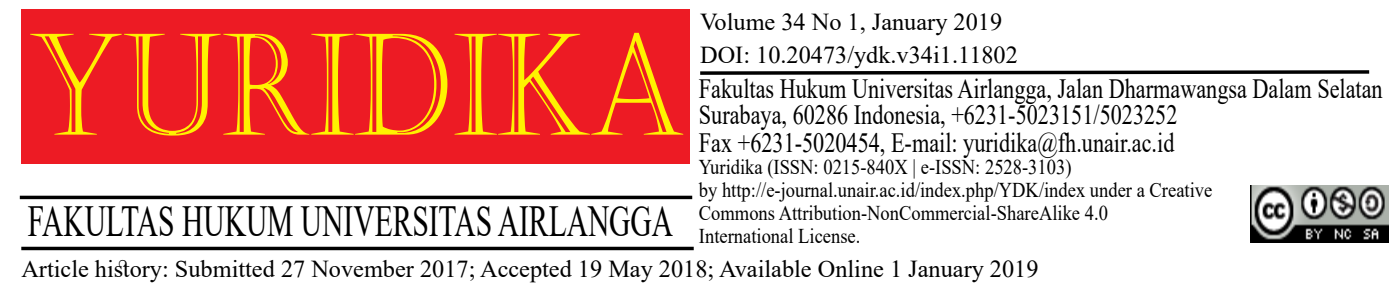

\title{
The Implementation of Unloading Agreements in the Port From Transportation Law Perspectives
}

\author{
Zahry Vandawati \\ zahry.vandawati@fh.unair.ac.id \\ Universitas Airlangga
}

\begin{abstract}
Sea transportation is a commercial shipping business that is regulated in the provision of sea freight services where its business activities are very broad in its field and plays an important role in advancing trade both domestically or abroad including in its efforts to expedite the flow of goods from production areas to consumer areas. In the Port, there are tools to facilitate and facilitate the demolition and loading of goods from or to ships, or equipment to take fuel, water supplies and so on. In ports, of course, there are loading and unloading companies that are always connected with Indonesian ports (Pelindo). This is certainly related to the entry and exit of ships. The loading and unloading company is an Indonesian legal entity established to carry out and carry out business activities for loading and unloading goods from and to ships. In loading and unloading services, there are loading and unloading service providers, namely companies that carry out loading and unloading activities (stevedoring, receiving and receiving/delivery using loading and unloading labor) and loading and unloading equipment. obstacles or obstacles that might occur, these obstacles must be studied more deeply so that the impacts or losses that might be suffered by the parties in the vessel loading and unloading agreement can be minimized. The legal method used in answering the legal issues raised is through statute approach, conceptual approach, and case approach.
\end{abstract}

Keywords: Transportation; Goods Loading and Unloading Agreement; Loading and Unloading Company; Port. 


\section{Introduction}

Article 1 of Law Number 17 of 2008 concerning Shipping (hereinafter referred to as the Shipping Law) states that the term sea transportation is used for transportation in the waters is the activity of transporting and/or moving passengers and/or goods by boat. Additionally, there are also important terms in sea transportation, namely:

a. Sea Transport is a transportation activity which according to its activities serves sea transportation activities;

b. River and Lake Transportation are transportation activities which include reservoirs, swamps, and canals;

c. Crossing Transportation is transportation that functions as a moving bridge that connects the road network and/or railroad network which is cut off due to the presence of waters.

As a service activity in moving goods or passengers from one place to another, transportation plays a major role in realizing the creation of a dynamic national distribution pattern. The practice of carrying out transportation must be able to provide maximum use value in the world of commerce. As well as in its implementation, it must be done fairly and equally to all levels of society and prioritize the interests of public services for the community. Transportation functions to move goods or people from one place to another with the intention of increasing usability and value. The process of transferring the goods is carried out by land, sea, air, and land or river waters using various types of transportation equipment according to their needs.

In Article 7 of the Shipping Law, it is stated that the type of sea transportation consists of domestic sea transportation, Foreign Sea transportation, Special Sea Transport, and People's Shipping Transportation.

1. Domestic Sea Transportation

Defined as the sea transportation activities carried out in Indonesian territorial waters organized by national sea transport companies or in the sense that they are carried out using sovereignty boundaries in the country.

2. Foreign Sea Transportation

Defined as the sea transport activities from special ports or terminals that are 
open to foreign trade, taken from foreign ports to special Indonesian ports or terminals which are open to foreign trade held by sea transport companies or in the sense that they are carried out in the free sea which connects one country to another.

3. Special Sea Transportation

The term is defined as transportation activity to serve its own business interests in supporting its main business.

4. People's Shipping Transportation

It is a traditional business of the people and has its own characteristics to carry out transportation in the waters by using sailing vessels, motorized sailing vessels, and/or Indonesian-flagged simple motorized vessels of a certain size.

According to Law Number 17 of 2008 concerning Shipping in Article 31, there are several service business activities at the port as supporting sea transportation activities, one of which is loading and unloading activities. Furthermore, according to Article 1 paragraph 14 Government Regulation No. 20 of 2010 concerning Transportation in the Waters, goods loading and unloading activities are business activities that are engaged in the loading and unloading of goods from and to ships in ports which include stevedoring, cargodoring, and receiving/delivery activities. This loading and unloading activity is one of the links of goods transportation activities by sea, where the goods to be transported to the ship require demolition to be moved both from the warehouse line and directly from the conveyance. Likewise, goods that will be taken down from the ship also need to be demolished and transferred to the warehouse line or directly to the next transportation equipment. With the increasing public demand for the presence of goods loading and unloading services companies through sea transportation, making the government try to regulate loading and unloading activities through the issuance of Presidential Instruction No. 3 of 1991 concerning the Policy of Ease Flow of Goods to Support Economic Activities.

In carrying out its business, the loading and unloading company must have a business permit issued by the Minister or appointed official. The business permit is given by the Head of the Regional Office of the Ministry of Transportation on behalf of the Minister. The loading and unloading company must implement the provisions stipulated in the business of loading and unloading companies. In organizing goods loading and unloading activities through sea transportation, loading and 
unloading companies have rights and obligations in carrying out their activities. Companies loading and unloading goods from and to ships are responsible for facilities used, ship loading and unloading equipment used in operating activities of loading and unloading goods. Besides that, the loading and unloading company is also responsible for the safety of goods loaded until the delivery to the recipient, the safety of the loading and unloading workers during the implementation of the activity, providing equipment and equipment to carry out the loading and unloading activities of adequate goods. ${ }^{1}$

Business activities of loading and unloading of goods in ports include in the field of supply and/or dock services for tethering, provision and/or dock services for the implementation of loading and unloading of goods and containers, provision of services and/or warehouse services and stockpiling, tools loading and unloading, port equipment, supply and/or container terminal services, liquid bulk, dry bulk, and supply and/or loading and unloading services. Every business must have risks and responsibilities in its implementation, as well as business in loading and unloading sea freight goods which have a high risk in carrying out their activities. In practice in the field, damage to goods in the process of loading and unloading is still common and results in no small losses. The owner of the item who does not want to receive the incident makes a claim and asks for compensation for the damage to the goods.

Determining liability in sea transportation concerning loading and unloading of goods is very important and closely related to the rights and obligations of the parties. This must be considered because any errors or omissions and other forms of default can be resolved based on existing rules. Therefore, separate rules are needed regarding sea transportation, both regulated by the international world and national regulations. One of the disputes that often arise in sea transportation is damage to goods which creates the right to claim compensation from the owner of the goods to the carrier. The emergence of claims from the owner of the goods in the form of damage to goods, it is important to note by the parties involved in the transportation

1 Martono and Eka Budi Tjahjono, Transportasi Di Perairan Berdasarkan UndangUndang Nomor 17 Tahun 2008 (Raja Grafindo Persada 2011).[119-120]. 
process to determine which party is truly responsible for the claim for compensation for damage to the item. From the background above, the legal issue that will be raised is about the implementation of the goods loading and unloading agreement at the port and the obstacles in practice.

\section{Implementation of Goods Loading and Unloading Agreement}

The role of sea transportation is very important for social, economic, government, defense, security, and other life, especially in inland areas such as in Indonesia. The advantages of sea transportation, in this case ships, compared to other modes of transportation are the transportation of goods by sea is very efficient compared to land and air transportation modes. Ships have a greater carrying capacity than other modes of transportation. ${ }^{2}$ So it is not surprising that most of the export and import activities prefer the use of sea transportation as the main mode of transportation. While ship itself cannot be separated from the existence of the port, this means that ports as sea transportation infrastructure have a very important and strategic role for industrial and commercial growth and are a major segment for types of businesses that can contribute to the economy and national development. This is because the port is part of the chain of transportation and logistics systems.

In accordance with PP No. 61 of 2009 concerning Port in Article 4, port has a role as a node in the transportation network in accordance with its hierarchy, the gate of economic activities, a place for transportation modes, supporting industrial and trade activities, distribution, production, consolidation of cargo or goods and realizing insight into the archipelago and the country's sovereignty. Given the importance of the port's role, effective, efficient and professional management is needed. So that port services are expected to be easy, safe and fast. ${ }^{3}$ The Indonesian port system was compiled into a hierarchical system consisting of around 1700

\footnotetext{
2 Abu Kusyairi and Endang Setyawati Hisyam, 'Analisis Kinerja Pelayanan Operasional Peti Kemas Di Pelabuhan Pangkalbalam Kota Pangkal Pinang’ (2016) 4 Jurnal Fropil.[2016].[75].

3 Adris A Putra and Susanti Jalante, 'Pengembangan Infrastruktur Dalam Mendukung Pembangunan Berkelanjutan' (2016) 6 Jurnal Ilmiah Media Engineering.[433].
} 
ports. There are 111 ports, including 25 major 'strategic' ports, which are considered as commercial ports and managed by four BUMNs, Perum Pelabuhan Indonesia (PT. Pelindo) I, II, III and IV. ${ }^{4}$

The transportation agreement in principle is one form of agreement that has generally been regulated in Article 1313 of the Civil Code, namely "an action by which one person or more ties himself to one or more other people". Based on the understanding of the agreement above, the definition of a transport agreement is "an event where a person promises to another person or where two people promise to do something". By looking at the understanding of the agreement in general above, it can be seen that as a result of the closing of the agreement, a legal relationship arises between the parties making the agreement to bind each other to each other. Given that an agreement is a legal relationship, certain conditions require safekeeping. In this case, Article $1320 \mathrm{BW}$ has arranged four conditions that must be fulfilled for the validity of an agreement, namely:

1. Agree that they commit themselves;

2. The ability to make an agreement;

3. A certain thing; and

4. A reason that is lawful.

The definition of a transport agreement in relation to the carrying out of transportation of goods by sea, in principle is carried out based on a transportation agreement, as stated by Soekardono, which formulates as follows "a reciprocal agreement, when the carrier binds itself to carry out transportation of goods or/ and people to a particular destination, while the other party (sender-recipient; sender or recipient; passenger needs to pay certain fees for the transportation.) In accordance with the understanding of the transportation agreement in general above, it can be formulated an understanding of the agreement to transport goods by sea, namely a reciprocal agreement between the carrier (shipping company) and the sender (goods owner), where the carrier binds himself to

\footnotetext{
4 Beny Agus Setiono, 'Analisis Faktor-Faktor Yang Mempengaruhi Kinerja Pelabuhan' (2010) 1 Jurnal Aplikasi Pelayaran dan Kepelabuhan <http://ww.hangtuah.ac.id/pdkk/images/stories/4_jurnal 1-pdp.pdf>.[42].
} 
carry out the transportation of goods by sea or by ship from one port to the port destination safely (safe and intact), while the sender binds himself to pay for the transportation fee. Considering the agreement to transport goods by sea is reciprocal, then the position of the parties (transporter and shipper) is equal or equal, so that it is different in nature from the labor agreement, where the employer's position must be higher than that of the laborer (subordinate in nature). Thus, the position of the parties in the agreement to transport goods by sea is coordination (gecoordineerd).

In the implementation of the goods transportation agreement by sea, the working relationship between the carrier and the sender is not continuous, but only occasionally (periodic service), that is when the sender needs a transportation service to deliver the goods. This is possible considering the nature of the transportation services is not fixed or if needed. This periodic agreement on the transportation of goods by sea, in principle, has been mentioned in Article $1601 \mathrm{BW}$, namely:

"In addition to agreements to carry out temporary services, which are governed by special provisions for that and by the conditions agreed upon and if not available, by custom, then there are two kinds of agreements with which the party binds itself to do work for the other party by receiving wages; labor agreement and job chartering".

From the formulation of the article above, it can be seen that regarding this periodic service agreement is not specifically regulated or further in BW. Considering the goods transportation agreement by sea is a periodic service, so the nature of the engagement tends to depend on the conditions agreed between the parties or depends on the prevailing customs. For this reason, it is possible for this transportation agreement to have dual characteristics, namely that it can be chartered or mixed, in addition to its nature as a periodic service, as described above.

In Article 1 letter (b) The Hamburg Rules provides a definition of a sea transportation agreement (contract of carriage by sea) which is an agreement that gives obligations to transporters to carry out transportation of cargo from one port to another port and the transporter has the right to receive wages payment. The contract of carriage by sea includes all forms of contract agreements that exist at 
sea. The transportation agreement is a reciprocal agreement between the carrier and the passenger or shipper. The carrier is obliged to carry out transportation safely, intact and secure.

The transportation agreement, especially in sea transportation, is usually manifested in a transportation letter which is proof of the transportation agreement. Letter of transportation made, binding the transporter and passenger or the sender of goods as well as the law, this is regulated in Article 1338 paragraph $1 \mathrm{BW}$; where it is said that all agreements made legally, apply as laws for those who make them. As an agreement in general, the transportation agreement also has consensual nature, meaning that the transportation agreement is formed if there is an agreement from the parties. The agreement of the parties can be concluded from the actions of the parties, namely by handing over the goods to be transported to the transporting party. Thus, that in this case the existence of a transport letter does not become mandatory but is still needed as a transport proof.

For shipping goods via sea transportation, the owner of the goods or the goods sender carries out a sea transport agreement (transportation agreement) with the national sea transport company. The transportation agreement must comply with Article $1320 \mathrm{BW}$ regarding the legal requirements of the agreement and at least contain the names of the parties namely ship owner (operator) and ship tenant or cargo owner, ship name, ship agency, flag, vessel position, type of cargo and amount, conditions of cargo contracts, mine money, willingness to ship, payment method, payment account, loading port, loading port, loading time, shipping of goods, receipt of goods, ship insurance, goods insurance, late cargo loading and unloading, conditions additional terms agreed together, disputes and signatures of the parties. When the parties have agreed to the agreement that has been made then immediately the owner of the goods and the transport company is bound in the transportation agreement so that the transporter must carry out transportation in accordance with what has been promised. While the owner of the goods is obliged to pay the transportation fee as agreed in the transportation agreement. The transport company in practice will then provide a document for 
booking a vessel called the shipping instruction. When the owner of the goods receives the shipping instruction, acceptance will take place at that time.

After carrying out the transportation agreement, the next important stage is when carrying out the loading and unloading process. Where the loading and unloading process will involve other parties outside the parties in the sea transport agreement. The party carrying out the loading and unloading process is called the loading and unloading company. Stevedoring companies in carrying out their duties based on Work Order (SPK) from national sea transport companies. Then the legal relationship that arises between the national sea transport company and the loading and unloading company is in the form of a power of attorney wherein the power agreement is subject to general provisions that apply to the agreement in general, which is stipulated in book III BW chapter 2 .

One of the provisions stipulated in Article 7 paragraph 1 of the Regulation of the Head of the Tanjung Priok Port Authority Number UK.112/2/10/OP.TPK.11 concerning Procedures for Ship Services and Loading and Unloading at the Tanjung Priok Port that the national sea transport company has the right appoint loading and unloading companies under LINER transport conditions and in the condition of Free In and Out Stowed (FIOS) transportation that has the right to appoint a loading and unloading company is the owner of the goods or their proxies. The condition of LINER's transportation is that the shipping carried out is fixed and regular, while the conditions of the transportation of FIOS are conditions where the costs of loading, unloading and compaction are borne by the owner of the goods or per charter.

According to B.S. Herman in the book Port Management \& Realization of Exports \& Imports, loading and unloading activities are activities to unload goods from the ship using a crane and the sling of the nearest ship on the edge of the ship, commonly called a dock, then from the dock using a truck, forklift or stroller, entered and arranged into the nearest warehouse designated by the Head 
of the Port (Syahbandar). ${ }^{5}$ Based on the Decree of the Minister of Transportation No. KM 14 of 2002 concerning the Implementation and Operation of Loading and Unloading of Goods from Ship (hereinafter referred to as Decree of the Minister of Transportation No. KM 14/2002) defines loading and unloading activities of goods to and from ships is an activity which includes stevedoring, cargodoring and receiving/delivery at ports. Stevedoring is the job of unloading goods from ship to dock/bark/trick or loading goods from the dock/bark/truck into the ship until arranged in the ship's hatch by using a ship crane or land crane; cargodoring is the work of releasing items from ropes or nets on the dock and transporting from the dock to the warehouse or stacking yard then arranging in a warehouse or stockpile of goods or vice versa; receiving/delivery is the job of moving goods from stockpiles or buildup in warehouses or stacking fields and submitting them until they are arranged on top of vehicles in the warehouse door or stacking yard or vice versa.

Loading and unloading activities from and to the ship are carried out through docks, warehouses and stacking sites at the port. This activity is carried out by a minimum of two parties, namely a loading and unloading company and a national sea transportation company. The obligation of the loading and unloading company is regulated in Article 12 of the Decree of the Minister of Finance No. KM 14/2002 namely:

a. Meet all obligations that have been stipulated in the business license;

b. Conducting business license activities, no later than six months after the permit is granted;

c. Submitting a report on planned loading and unloading activities to Port Administration (Adpel) or Head of the Port (Kakanpel) no later than one day before the loading and unloading activities are carried out;

d. Submitting monthly reports on operational activities to the issuing authority with ransom to Port Administration (Adpel) or Head of the Port (Kakanpel);

e. Submitting an annual report on operational activities to the issuing authority with ransom to Port Administration (Adpel) or Head of the Port (Kakanpel);

\footnotetext{
${ }^{5}$ Minto Basuki,[at.,al.], 'Analisis Risiko Kegiatan Bongkar Muat Sebagai Komponen Dweling Time Di Pelabuhan' (2015) 2 Jurnal ITATS < http://jurnal.itats.ac.id/analisis-risiko-kegiatan-bongkar-muat-sebagai-komponen-dwelling-time-di-pelabuhan/>.[512].
} 
f. Reporting to the official granting permission, whenever there is a change in the basic budget, name, address, tax ID number (NPWP), name or address of the president director and ownership status of work equipment no later than 14 days after the change occurs;

g. Participate in creating operational cooperative relations with any party related to port activities;

h. Comply with and implement health and safety in the environment of the company's activities and for all workers employed;

i. Educating and training employee skills to achieve work effectiveness and efficiency;

j. Participate in creating images and improving port performance; and

k. Report operational activities in accordance with the material requested by and to the competent authorities for the sake of data and statistics.

The responsibility of the loading and unloading company is regulated in Article 13 paragraph 1 of the Minister of Finance Regulation No. KM 14/2002, namely the loading and unloading company is responsible for port facilities used and parts of ships and ship loading and unloading equipment used in loading and unloading operations. However, it does not rule out the possibility that the parties make additional provisions in the agreement agreed upon by the parties concerned. In addition to Article 13 paragraph 2 of the Ministerial Decree No. KM 14/2002, the loading and unloading company is also responsible for the loss of one's life or injury, and loss from the loss or damage to property or property belonging to third parties due to errors and/or negligence in carrying out their duties. So that in this provision there must be proof, whether the loss is due to mistakes made by the loading and unloading company. Thus, as to reduce the risk, the loading and unloading company can ensure its responsibility to the insurance company.

The next party is a national sea transport company, the company is an Indonesian legal entity that carries out sea transportation activities in Indonesian territorial waters and/or goes to ports or from overseas ports. The loading and unloading company activities are limited to real ships and/or vessels or charters of passenger property, liquid sura goods which are unloaded or loaded are carried out through pipes, dry bulk goods which are disassembled and loaded through the conveyor or vice versa, goods transported through Ro-Ro ships and 
all types of goods at the port where there is no loading and unloading company. Through this description, loading and unloading activities are not only carried out between the parties that entered into the agreement, namely the goods loading and unloading company with the national sea transportation company but also for the agreement binding other parties involved in it. The parties each have a role and relationship to each other for the smooth process of loading and unloading at the port, the parties are:

1. Shipload Expedition (EMKL);

2. Unloading Workers (TKBM);

3. Work in Warehousing and Warehousing;

4. Transportation Fleet;

5. Ports and Customs Processes;

6. Surveyor (TKBM supervisor).

Methods for handling container loading and unloading can generally be divided into two types, namely, lift on/lift off (Lo/ Lo) and roll on/roll off (Ro/ Ro). At present, the handling of containers is mostly done using equipment placed on the dock. The tool commonly used is gantry crane. To handle cargo on land, it can be done using the straddle loader/carrier. Side loaders are also used to lift containers and stack them in three levels. Another tool is Rubber Tyred Gantry (RTG), this tool is able to stack containers up to four levels and can be used to place containers on railroad cars or chassis truck. ${ }^{6}$ Unloading documents are the unloading by plan, manifest, tally sheet, timesheet, statement of fact, road letter (EIR) and handover of goods and for loading documents are loading by plan, lapagan by plan, manifest, loading list, daily report, tally sheet, timesheet and statement of fact. The following is the flow of goods services through cargo and containers as follows:

\footnotetext{
6 Mudjiastutik Handajani, 'Analisis Kinerja Operasional Bongkar Muat Peti Kemas Di Pelabuhan Tanjung Emas Semarang’(2004) 4 Jurnal Transportasi<https://docplayer.info/32160671-Analisis-kinerja-operasional-bongkar-muat-peti-kemas-pelabuhan-tanjung-emas-semarang.html>.[3-4].
} 


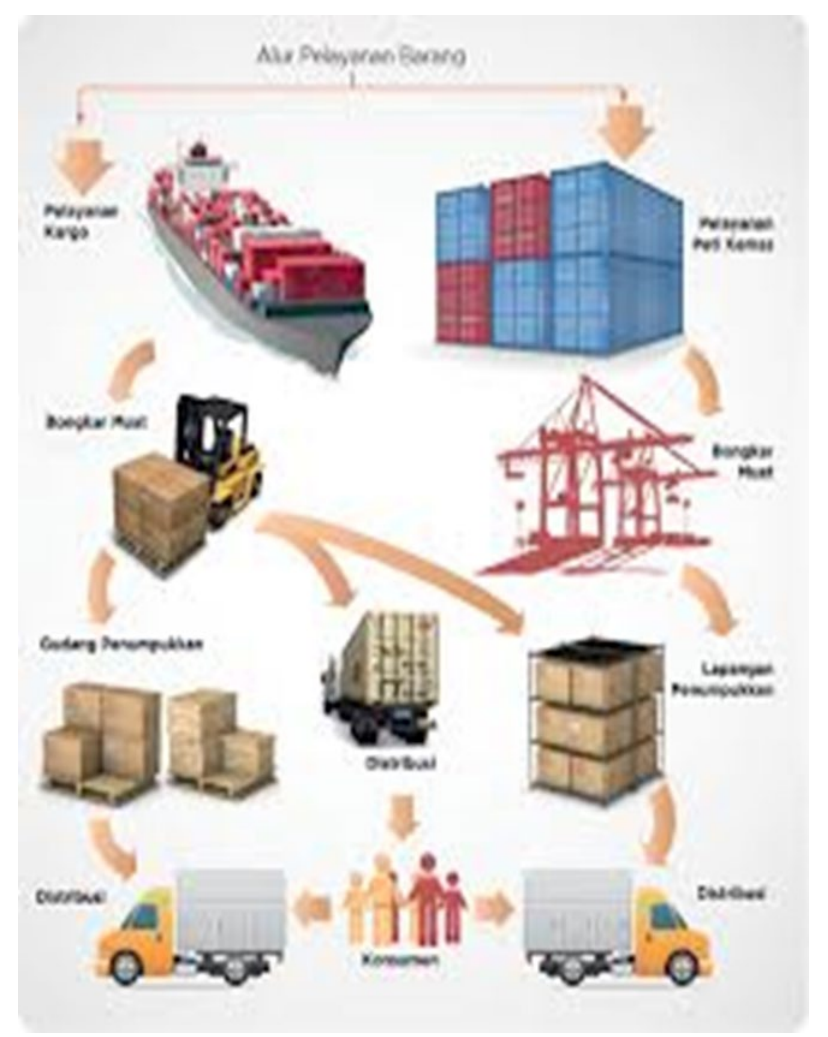

Source: http://www.indonesiaport.co.id/read/cargo-services.html

Stevedormanship activities from and to ships in ports are usually carried out in three types of terminals and also warehouses/fields, namely:

1. Conventional Terminal is a terminal for serving loading and unloading activities of general cargo, dry bulk goods, and liquid bulk goods. In conventional terminals, container loading and unloading, especially between islands by using loading and unloading equipment, is mostly carried out by private loading and unloading companies.

2. Container Terminals, equipped with modern container equipment such as postPanamax container cranes (gantry cranes). In addition, the terminal is also equipped with equipment for handling and transporting containers such as trainers, roadblocks, forklifts, cranes, top loaders, and others.

3. Passenger Terminal, there are no loading/unloading activities, but only serve debarkation or embarkation of passengers from inside and outside the country.

4. Warehouse/Field (Multipurpose Terminal), the storage warehouse is usually located not so far from the conventional terminal. In Indonesia, these warehouses are a Dutch Colonial legacy which was then taken over by the government and delegated to PT. Pelindo.

Presently, those conducting activities at conventional terminals are loading and unloading companies (PBMs) authorized by PT. Pelindo through a contract. Activities 
from and to warehouses used to be done manually, namely goods carried by workers to the warehouse. Similarly, the stacking activity is done manually. In the next development, goods from the ship are transported using a wheelbarrow. However, until now manual work items are still difficult to remove from ports in Indonesia.

In the current container era, labor is still needed to do stuffing and container stripping. Previously with PP No. 61/1954 on determination of regulations regarding companies for sea ship and PP No. 5/1964 on management and sea transportation, work on the dock and warehouse in line 1 was entirely held by PBM so that loading and unloading of goods could be carried out in an integrated manner. This model facilitates settlement if claims arise due to damage or loss of goods. With the Inpres No. 4/1985 on Policy on the smooth flow of goods to support economic activities, loading and unloading companies became separate legal entities apart from shipping. Warehouses and docks are under the control of PT. Indonesian Harbor. Regarding the role of loading and unloading companies, loading and unloading companies only provide services (laborers) for loading and unloading activities from warehouses to ships and ships to warehouses.

\section{Obstacles in the Implementation of the Goods Loading and Unloading Agreement at the Port}

North Jamrud Terminal is one of the terminals at PT. Pelindo III Tanjung Perak Branch where its main business is as a port facility service provider that has a key role in ensuring the continuity and smoothness of sea transportation. ${ }^{7}$ PT Pelindo III (Persero) Tanjung Perak Branch recorded an increase in container loading and unloading by 31 percent in the first six months of 2017. The increase in container loading and unloading performance was also in line with the increase in ship visits, especially from large weighted vessels. The total container loading and unloading during the first semester of 2017 reached 287.91 TEUs or grew

\footnotetext{
7 Luhur Prasetyo and Beny Agus Setiono, 'Pengoptimalisasian Kegiatan Bongkar Muat Untuk Meningkatkan Produktivitas Kerja Terminal Jamrud Utara PT Pelindo III Tanjung Perak' (2011) 2 Jurnal Aplikasi Pelayaran dan Kepelabuhaan.[1].
} 
31 percent on an annual basis. When using box units, the number of loading and unloading boxes at Tanjung Perak reached 261.686 boxes, up 32 percent on an annual basis. In the six months of 2017, the flow of ships reached 43.335.141 GT, up 2 percent compared to the same period last year of 42.516.151 GT. For noncontainer loading and unloading, Tanjung Perak Port also recorded an increase of 0.2 percent to 8.058 .694 tons. Meanwhile, liquid bulk loading and unloading were recorded at 1.137.849 tons, up 12 percent. Tanjung Perak Port also prints animal flows by 1 percent to 9.545 tails or 1 percent higher than the target of 9.446 . On the other hand, passenger flows also experienced a slight increase of 1.46 percent to 209.261 people. The number consists of 203,015 domestic passengers while the rest are passengers from abroad. ${ }^{8}$

In carrying out development and development in the field of sea transportation, direction and policy are needed. The direction and development policy of sea transport is carried out functions, among others: ${ }^{9}$

1. Increasing the role of the national shipping fleet, both for domestic transportation and import-export by enforcing the cabatage principle. For this reason, banking support is needed in providing cheap credit for fleet rejuvenation.

2. Reducing and even removing unofficial levies at ports, so that the tariffs set by the port authorities are not much different from those that are actually issued by port service users, through increased coordination for all agencies involved in the loading and unloading process.

Since the enactment of Law Number 17 of 2008 concerning Shipping, until now the problems regarding the operation of sea transportation activities, especially in the business of loading and unloading services, there has always been a disharmony between various parties involved in the port, including Asosiasi Perusahaan Bongkar Muat Indonesia (APBMI), Tenaga Kerja Bongkar Muat

\footnotetext{
8 Tempo.co, 'Pelindo Catat Bongkar Muat Di Tanjung Perak Naik 31 Persen' (Tempo.co, $2017)<$ https://bisnis.tempo.co/read/892197/pelindo-catat-bongkar-muat-di-tanjung-perak-naik-31persen $>$ accessed 28 August 2017.

9 Ofyar Z Tamin, Perencanaan Dan Pemodelan Transportasi Institut Teknologi Bandung (Institut Teknologi Bandung 2000).[31].
} 
(TKBM), PT. Pelabuhan Indonesia (Persero) which is a State-Owned Enterprise as the manager of most terminals in ports in Indonesia, and the government, in this case, the Ministry of Transportation. The form of the problems that occur are related to business licensing problems, loading, and unloading responsibilities, the amount of labor costs, among the business actors. So if the data is one by one, the obstacles that can be found in the loading and unloading agreement at the port in general is that it can be seen from two aspects, namely the first one is juridical barriers, including obstacles related to regulations issued either directly or can indirectly cause harm to the parties. Jurisdictional barriers are rarely found because in general port laws and regulations are good enough. The second obstacle is the general obstacle associated with the sender of goods with the owner of the goods. The third obstacle is technical barriers, including obstacles found during the process of implementing the work (obligations) in accordance with what is stated in the agreement, especially when the ship is docked / the process of demolition of goods where the process of unloading goods. This obstacle is still commonly found in the practice of loading and unloading goods at the port.

The first general obstacle is that in the implementation of the loading and unloading agreement, the charterer is sometimes late in paying the freight costs agreed upon by both parties, in other words, that the payment is not according to the agreed upon schedule. This is sometimes difficult for ship owners. The second obstacle is the cancellation of ship departures carried out by the owner of the ship which is a sudden cancellation due to unclear reasons. The third obstacle is the number of loading and unloading companies at the port, but on the other hand, the volume of work remains. In addition to the next obstacle, there are also several loading and unloading companies that do not use the APBMI tariff reference. The fifth obstacle is related to bureaucracy, the absence of a clear match between work activities and systems, which are in agreement (more flexible) and can change due to the existence of good relations between interested parties.

The technical barrier is that it can be a natural factor such as bad weather or rain. Then the next obstacle can be a factor of loading and unloading equipment, 
which is limited or incomplete. The next obstacle is related to human resources, such as lack of professionalism or lack of discipline in the TKBM and surveyors (TKBM supervisors). Another obstacle that often occurs is in the form of land transportation (truck) for goods loading or unloading facilities that are inadequate. ${ }^{10}$ Another obstacle is the condition of the goods, such as items that are very large in weight so that they require more labor and special equipment.

The above obstacles can be minimized if there is good coordination between the parties in the sea transportation process. This means that from the time of the agreement between the sender of goods and transportation (the shipowner) must be able to fulfill their obligations. as regulated in Article 468 of the KUHD, wherein the article is regulated regarding the main obligations of the carrier. ${ }^{11}$ The sea transport agreement carried out by the parties is bound to other parties such as loading and unloading companies, surveyors, loading and unloading workers, ports, transportation fleets, expeditions who each have a very important role in the transportation process until the goods are received by the owner goods. All these parties carry out their functions and must comply with the rules or agreements that have been agreed upon by the parties. In addition, it must continue to improve the facilities needed in sea transportation and loading and unloading of goods. The above has also been regulated in the Minister of Transportation Regulation No. PM 93 of 2015 concerning the Second Amendment to the Minister of Transportation Regulation No. PM 60 of 2014 concerning the Implementation and Operation of Loading and Unloading of Goods from and to Ships. ${ }^{12}$ If this is fulfilled and adhered to, the practice in the port will be better and more effective.

10 Suraini, 'Tanggung Jawab PT Pelindo II Terhadap Kerusakan Barang Dalam Perjanjian Bongkar Muat Di Pelabuhan Teluk Bayur Padang' (Universitas Andalas 2017) <http://scholar. unand.ac.id/23522/>.[49].

11 The main obligation of the carrier is to send goods to the destination safely and safely, pay compensation in the event of damage to the goods either in whole or in part and is responsible for the mistakes of the crew so that damage to the goods sent.

${ }^{12}$ In the Minister of Transportation Regulation No. PM 93 of 2015 concerning the Second Amendment to the Minister of Transportation Regulation No. PM 60 Know 2014 Regarding the Implementation and Business of Loading and Unloading of Goods to and from Ships. Regulating the competence of the loading and unloading staff, the feasibility of loading and unloading equipment and the safety of workers. 


\section{Conclusion}

The execution of loading and unloading agreements is always preceded by a sea transport agreement between the shipper and the shipowner. The loading and unloading agreement is carried out by the owner of the ship or carrier with the loading and unloading company located at the destination port. In practice, the form of loading and unloading agreements is limited to the Letter of Employment (SPK) from the carrier to the loading and unloading company. SPK made between the parties, is also tied to third parties such as to loading workers, ship freight expeditions, surveyors, transportation and investment fleets and customs processes. The loading and unloading agreement is in agreement with the general agreement that is to contain the provisions of Article $1320 \mathrm{BW}$ jo Article $1338 \mathrm{BW}$. In loading and unloading practices, of course, there are some obstacles or constraints that are constraints that come from juridical aspects (regulatory provisions), general constraints and technical constraints that will all be minimalized if all the parties involved in the sea transport range are able to perform their functions accordingly with existing and mutually agreed terms.

\section{Bibliography}

Abu Kusyairi and Endang Setyawati Hisyam, 'Analisis Kinerja Pelayanan Operasional Peti Kemas Di Pelabuhan Pangkalbalam Kota Pangkal Pinang' (2016) 4 Jurnal Fropil.

Adris A Putra and Susanti Jalante, 'Pengembangan Infrastruktur Dalam Mendukung Pembangunan Berkelanjutan’ (2016) 6 Jurnal Ilmiah Media Engineering.

Beny Agus Setiono, 'Analisis Faktor-Faktor Yang Mempengaruhi Kinerja Pelabuhan' (2010) 1 Jurnal Aplikasi Pelayaran dan Kepelabuhan $<$ http:// ww.hangtuah.ac.id/pdkk/images/stories/4_jurnal 1-pdp.pdf $>$.

Luhur Prasetyo and Beny Agus Setiono, 'Pengoptimalisasian Kegiatan Bongkar Muat Untuk Meningkatkan Produktivitas Kerja Terminal Jamrud Utara PT Pelindo III Tanjung Perak' (2011) 2 Jurnal Aplikasi Pelayaran dan Kepelabuhan.

Martono and Eka Budi Tjahjono, Transportasi Di Perairan Berdasarkan UndangUndang Nomor 17 Tahun 2008 (Raja Grafindo Persada 2011). 
Minto Basuki,[at.,al.], 'Analisis Risiko Kegiatan Bongkar Muat Sebagai Komponen Dweling Time Di Pelabuhan' (2015) 2 Jurnal ITATS $<$ http://jurnal.itats.ac.id/ analisis-risiko-kegiatan-bongkar-muat-sebagai-komponen-dwelling-time-dipelabuhan/>.

Mudjiastutik Handajani, 'Analisis Kinerja Operasional Bongkar Muat Peti Kemas Di Pelabuhan Tanjung Emas Semarang' (2004) 4 Jurnal Transportasi $<$ https:// docplayer.info/32160671-Analisis-kinerja-operasional-bongkar-muat-petikemas-pelabuhan-tanjung-emas-semarang.html>.

Ofyar Z Tamin, Perencanaan Dan Pemodelan Transportasi Institut Teknologi Bandung (Institut Teknologi Bandung 2000).

Suraini, 'Tanggung Jawab PT Pelindo II Terhadap Kerusakan Barang Dalam Perjanjian Bongkar Muat Di Pelabuhan Teluk Bayur Padang' (Universitas Andalas 2017) <http://scholar.unand.ac.id/23522/>.

Tempo.co, 'Pelindo Catat Bongkar Muat Di Tanjung Perak Naik 31 Persen' (Tempo. co, 2017) <https://bisnis.tempo.co/read/892197/pelindo-catat-bongkar-muatdi-tanjung-perak-naik-31-persen> accessed 28 August 2017.

HOW TO CITE: Zahry Vandawati, 'The Implementation of Unloading Agreements in the Port From Transportation Law Perspectives’ (2019) 34 Yuridika. 
--This page is intentionally left blank-- 